\title{
SOCIAL ACTIVITIES OF THE NGOS FOR OVERCOMING AGGRESSION IN CHILDREN FROM ROMA COMMUNITIES
}

\author{
M. Ilieva*, R.Vassilev \\ Department of Social Activities, Faculty of Medicine, Trakia University, Stara Zagora, Bulgaria
}

\begin{abstract}
This article deals with the activities performed by the non-governmental organizations for overcoming aggression in children from Roma communities. It outlines the challenges faced by the people working with vulnerable groups as well as the state policies intended to overcome aggression. Presented are some good practices from the work with children focused on reducing aggressive behavior in the out-of -school environment.
\end{abstract}

Key words: roma communites, social activites, aggression

\section{INTRODUCTION}

In Bulgaria over the recent years widely discussed is the progress issue which is also causing problems in our educational system. The increasing number of the acts of aggression in children including also the children of Roma ethnical origin since they are the most numerous ethnical group, remains unsolved and one of the most complicated problems.

The socio-economic changes in the modern society of Bulgaria led to a painful widening and deepening of the problems of the Bulgarian citizens of Roma origin. A bigger part of the Bulgarian Roma people are unemployed or on a low income. This places their families in difficult economic conditions in terms of their existence and survival. Their children grow up chronically undernourished and deprived of a basic standard of living. Their constant companions- poverty and hunger at a very early school age drive them into criminal offences such as begging, thefts and prostitution.

Because of these hard living conditions in the Roma communities, a major part of the Roma children do not attend school, their intellectual development lags behind, they remain illiterate

\footnotetext{
* Correspondence to: Milena Ilieva, PhD,

Department of Social Activities, Faculty of

Medicine, Trakia University, 11 Armejska str., 6000

Stara Zagora, Tel.: 042/644417, Mobile:

0878700509,e-mail: mimiilieva@abv.bg
}

or semi-literate which results in limited possibilities for demonstration of their skills and abilities in various human activities.

We are witnessing a vicious circle. On one hand, Roma people being uneducated, are unable to find a job and do not meet the requirements of the employers in the private sector. On the other hand, the stigma that is marked on a very small number of Roma people who have the knowledge, skills, experience and high-quality education, prevents them from finding a job on the labor market. In this way, Roma people are pressed by the absence of a role model to follow and education is not a priority in their value system. At the same time, every Roma person wants a better future for his/her children.

\section{MATERIALS AND METHODS}

The specifics of the study required use of complex methods:

Theoretical analysis;

Documentation analysis;

\section{DISCUSSION}

Another aspect of these negative processes is the permanent isolation of Roma children from the life and work of the people from the other communities because of unawareness and unwillingness to explore the «foreign» customs, traditions and culture. It is necessary and it is possible to overcome this ethnic isolation and alienation. The opinion of the other people should be based on personal contacts with representatives of the ethnic 
communities and not on the basis of the negative media statements.

These key factors have an impact on the permanent isolation of Roma people and their incomplete participation in the public activities, reduced possibilities for integration of the Roma adults and adolescents in the entire society living on the territory of this country. In the course of time, the process of isolation is getting more serious opposed to the globalization trends in the society and is more significantly counteracting the integration process in the public relations, resulting in an increased number and increased seriousness of the aggressive acts of behavior in adolescents.

We are going to give a common example. Children raised in a relatively closed or isolated Roma community up to the time they start school, have had communication mainly in their mother Romani tongue. In this regard, when they start school, these children find themselves in a disadvantaged position. They have to perceive totally new academic content in a language they have no command of. This unequal start results in lagging behind in the acquiring of new knowledge. Roma children start to show uncertainty, lack of confidence and low self-esteem. This usually leads to reluctance to learn, hostility towards the good learners and self-isolation. Those children get no adequate support from the school authorities and their Bulgarian peers.

The school institution is left to deal with education, and in the opinion of some people also with teaching good manners. The state policy focused on dealing with aggressive behavior of pupils has its own institution- The Central Commission for Combating Juvenile Delinquency and its local departments- local commissions for combating juvenile delinquency.

In addition, after the democratic changes, one of the services in the community- Community Support Centre (on its own and / or as part of the Complexes for social services for children and elderly people) provide various types of services for prevention of the aggression in adolescents.

The respondents, i.e. 30 non-governmental organizations which run Community Support Centers and work for preventing aggression, talk about the most common consultation activities aiming at solving personal and social problems of the consultees (emotional problems, problems with communication, adaptation, etc.)
- consultations in the field of social affairs;

- legal consultations;

- support and individual workpsychological consultations, accompanying;

- $\quad$ support and group work;

- corrective and educational work;

- corrective and psychological work;

- advising-indirect, direct and by means of compromise;

- consultation on issues related to professional orientation and preparation for a future career;

- elaboration and completion of individual programmes for social inclusion;

- individual work with the child and the child's family;

- activities related to primary and functional literacy (elementary reading, writing, using a computer);

- participation in small and big groups (in order to acquire social skills)

The thesis output of those working in the field of prevention, is the corrective work and the change to be overcomed painlessly and without contradictions. This implies the involvement of games, building of habits and teaching behavioral norms, raising the self-esteem and strengthening the family values as unique. Here the focus is on the smooth transition from impact to correction by using stimulus and without punishment but in a relationship of equality.

Here are examples of role-playing games which are quite popular. At the same time, the impact they have on children and the subsequent changes are significant. These are also an example of good practices in prevention work.

\section{The Compliments Game \\ 1. Cognitive tasks}

Teaching the meaning of the word "compliment" and different ways to formulate and pay appropriate compliments by identifying the emotional state of the other person.

Differentiation of the personal characteristics of the other person.

\section{Playing task}

Children are invited to paint what they like best in their play partner.

Based on what is painted, children are invited to formulate and pay an appropriate 
compliment to their partner. Through an insight into the content of the compliment, the other children in the group are expected to guess what was painted by the child paying the compliment.

\section{Material supply}

White painting sheets of paper, colour pencils, marker pens

\section{Game rules}

$\Rightarrow$ All children divided into pairs take part in the game;

$\Rightarrow$ Children divide themselves into pairs of their own choice;

$\Rightarrow$ The children from each pair shall sit opposite each other and shall paint what they best like in their partner;

$\Rightarrow$ After everyone has finished their painting, each child shall pay a compliment to his/her partner based on what has been painted.

\section{Course of the game}

The teacher invites the children to divide themselves into pairs of their own choice. Children are invited to sit at the tables facing each other and using the painting paper in front of them to paint what they best like in their partner. After every child has finished their painting, children are invited to pay a compliment to their partner based on what has been painted. The rest of the children shall have to guess what each child has painted based on the compliment paid. (If computers are available with the Comenius Logo software, the Comenius Logo Painter is to be used).

At the end of the game, each child talks about the role he/she best liked.

\section{Game variants}

Children pay compliments without looking at the child the compliment is directed to and without saying his/her name. The rest of the children are expected to guess whom the compliment was intended for.

\section{The Portrait Painting Game}

\section{Cognitive tasks}

Teaching the rules of effective listening (not to interrupt the interlocutor, the listener shall not get involved with other activities)

Improving the ability to verbally describe the personal features of others and differentiating them.

\section{Playing task}

The child, performing the role of the painter is invited to "paint" the portrait of another child, performing the role of the model, using words.
The child, performing the role of the model, shall have to remember and repeat precisely those phrases from the description of the "painter" which he/she finds most interesting.

\section{Material supply}

\section{Game rules}

- All children shall take part in the game;

- Pairs are formed by the teacher by counting-out rhymes;

- After the children have performed the role of the painter and the role of the model, roles are exchanged.

The winning pair is the pair in which the painter has described the model most accurately and in details, and the model has succeeded in repeating the biggest number of phrases used as part of the description.

\section{Course of the game}

The teacher divides the children into pairs. At first, one of the children performs the role of the painter and the other-the role of the model.

The task of the painter is to "paint" the model using words, and the model has to remember and repeat precisely some of the phrases used by the painter which he/she finds most interesting.

Role exchange follows.

At the end of the game, each of the children talks about the role which he/she liked best.

\section{Game variants}

The painter describes verbally a child chosen by him/her without saying his/her name and the rest of the children are expected to guess whom the description refers to.

\section{Find the Other Person Game \\ 1. Cognitive tasks}

Children master their recognition and differentiation skills by perception of the other child's outer appearance and by the help of their own hands.

\section{Playing task}

Children are expected to identify and find their peer pointed out in advance by touching his/her hair, hands, clothes alone.

\section{Material supply \\ Blindfolds}

\section{Game rules}

- The teacher divides the children into pairs of their own choice;

blindfolded. 
- $\quad$ Upon a signal, children start to freely walk around the room;

The blindfolded children are expected to find their partner.

- When children find their partner, roles are exchanged

\section{Course of the game}

The teacher invites the children to divide themselves into pairs of their own choice.

After pairs have been formed, the teacher blindfolds one of the children from each pair.

Upon a signal of the teacher, the children start to freely walk around the room. Every blindfolded child is expected to find his/her partner using his/her hands and by touching the hair, clothes, hands of the other children. When each child has found his/her partner, roles are exchanged.

At the end of the game, all of the children talk about their behavior and what they liked best in the game.

\section{Game variants}

One child only is blindfolded who by touch alone is expected to identify the other children in the group.

\section{CONCLUSION}

From the above-mentioned arguments, it is clear that a significant broadening of the social horizon is needed together with improved life perspectives for Roma children / and in particular prevention of aggressive behavior in Roma children /.

This can be achieved through mutual acquaintance and participation in joint socialization between children of different ethnic groups which starts at a very early age. In this connection, it is extremely important to provide equal access to high-quality education for the adolescents in the Roma neighbourhoods in almost each place of Bulgaria in an atmosphere of on-going desegregation, taking into account the influence of the sub-group characteristics and by improving the access to nurseries and kindergartens at a very early age.

\section{REFERENCES}

1. Шошева, В.,И. Дерижан, К. Бенкова, С. Динчийска, Е. Масларова, Г. Вълчев, А. Стойков, М. Илиева, Р. Райкова. Интегриране на ученици със специални образователни потребности в условията на общообразователното училище. Учебно помагало за учители. София,2013. 